\title{
Short-Run Money Growth Fluctuations and Real Economic Activity: Some Implications for Monetary Targeting
}

\section{DALLAS S. BATTEN AND R. W. HAFER}

\begin{abstract}
T HERE is ample evidence that the rate of inflation is directly related to the long-tem growth of the money stuply. Indeed, this relationship has been demonstrated for various countries. ${ }^{\text {t }}$ The implication of this finding is that the control of money growth over the long term is vital to the control of inflation, a realization that undoubtedly helps to explain the fairly recent announcenents of monetary growth targets in most of the major industrial countries. ${ }^{2}$
\end{abstract}

Although the money growth/inflation connection is fairly well-documented, the relationship between short-min movements in money growth and economic activity is less well-known. Even though this connection has been demonstrated for the United States, its general applicability has not been tested. ${ }^{3}$ The purpose of this article, therefore, is to investigate the relationship between short-run movements in the growth of the money stock and

\footnotetext{
"Dallas S. Battem, "Money Growth Stability and Inflation: An Intemational Comparison," this Retiew (October 1981), pp. 712. See also Richard T. Selden, "Inflation and Monetary Growth: Experience in Fouteen Countries of Europe and North America Since 1958," Federal Reserve Bank of Richmond Economic Review (November/December 1981), pp. 19-35.

2Of the Group of Ten countries plus Switzerland, only two, Belghum and Sweden, do not formatly annonnce monetary growth targets of some kind. See Organization for Economic Co-opention and Development, Monetary Tardets and Infation Control (Paris:OECD, 1979).

Milton Frietmin and Ama $\mathrm{J}$. Schwartz "Money and Business Cycles,"Retieu af Economics and Statistics (February 1963), pp. 32-78; Willmim Pole, "The Relationship of Monetary Decelerations to Business Cycle Peaks: Another Look at the Evidence," Joumal of Finance (June 1975), pp. 697-712; and Leonall C. Andersen and Keith M. Carlson." A Monetarist Vodel for Exonomic Stabilization," this Reciece (April 1970), pp. 7-25.
}

fluctuations in real economic activity, ${ }^{4}$ Although the evidence presented in this article is not derived from a rigorous empirical analysis, if indicates quite convincingly that virtually every downtum in economic activity in recent years in each of the countries examined was preceded by a significant reduction in the growth of its narowly defined money supply.

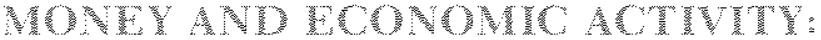 THE THOSPY}

There is little disagreement that significant changes in the grow th of the money supply influence economic activity. Changes in the longuterm growth of money, measured by some moving average of money grow th over a number of years, affect the rate of inflation. Indeed, several empirical studies of the United States indicute that it may take as long as five years for the rate of inflation to reflect completely the impact of a change in money grow th. ${ }^{5}$ More recent

"The evidence presented also sheds light on the debate about the impact of $\mathrm{Ml}$ growth during periods of fumcial innovation and mustitutional change. By examining the connection between short-rom factuations in $M 1$ growth and real economic activity across countries with different financiat institutions anc regulations, some understanding of the relationship 's cobustness in a changing finamed emolomment mat be ganed. For a good example of the metertainty that pervades carrent thinking on the fiature efficacy of turgeting on MI, see Authony $\mathrm{M}$. Solonon, "Finandal Inovations and Monetary Policy," Federal Reserve Bank of New York, Ammal Repent, 1981 (1982), pp. 3-17; and Fdward Yardeni, E. F. Hutton Economies Alert January 29, 1982).

${ }^{5}$ See Denis $\$$. Kamosky, "athe Link Between Money and Prices 1971-76," this Retiet (Jume 1976), pp. 17-23; Keith M. Carlson, "The Latg From Money to Prices," this Rowew (Oxtober 1980), p13. 3-10, and John A. "iatom, "Energy Prices and Short-Ran Economic Performance," this Reten (Jamary 1981), pp. 3-17. 
studies also have demonstrated that a lengthy lag between money growth and inflation is common in several industrial countries. ${ }^{6}$ This evidence indicates that changes in current money growth have a relatively small impact on prices in the short run.

For short-run changes in money growth to affect economic activity, they must initially influence the real economy more significantly than they infuence prices. ${ }^{7}$ Indeed, studies have shown that, at least for the United States, sizable reductions in money grow th below its established trend rate for only a few quarters have preceded declines in real economic activity ${ }^{8}$

The economic theory that "predicts" the results just described is as intuitively appealing as it is empirically verifiable. A marked and sustained decline in the growth of the money supply creates a "monetary disequilibrium": the quantity of money that individuals desire to hold exceeds the quantity that they are actually holding. By reducing their spending, they can increase their money holdings to a desired level. Eventually, this reduced spending will cause the rate of inflation to fall.

In the short run, however, producers who cannot tell immediately whether this decline in aggregate demand (spending) is permanent or just a temporary aberration initially react to the reduction in money growth (and spending) by reducing output. Therefore, the decline in money growth results in a slowdown in economic activity; if it is pronounced enough and sustained long enough, it can produce a recession. Only when the decline in spending (motivated by the monetary disequilibrium associated with the reduction in money grow th) has been identiffed as permanent will producers reduce their prices and increase production back to "nomal" levels. Thus, the impact of the monetary contraction on output eventually vanishes, and, in the long rum, only the rate of infation is affected by a sustained reduction in money growth. ${ }^{9}$

The potential usefulness of monetary tangeting for economic policy purposes is evident from this dis-

\footnotetext{
"Batten, "Money Growth Stability and Infation;" itud also

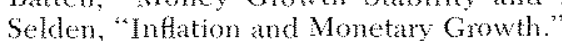

This article discusses only the impact of changes in mones grow th on the real output of the economy. It does not investigate the impact of money growth changes on financial makets.

8poole. "The Relationship of Monetary Decelerations to Busines: Cycle Pesks." See alko Ecomomic Report of the President (Gow emment Printing Offee, 1982), pp. 19296 , for another use of the theory presented here.

The empirical probum here, of conse, is dating the "Iongrem."
}

cussion. First, in the long rum, permment changes in the rate of money growth are reflected by equivalent changes in the rate of inflation, other things equal. Second, if short-rum money growth is volatile, the growth of real output and employment will be similarly volatile. In other words, sufficiently unstable money growth in the short run, that is, a reduction in money growth relative to its trend rate, may cause recessions. Consequently, minimizing the variability of short-run money grow th appears to be essential in establishing a stable, non-inflationary environment for economic growth.

\section{SHORT.RUN MONE GPONTH

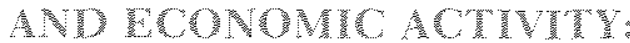

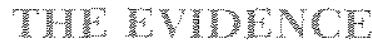

We now investigate the validity of the conceptual analysis presented in the preceding section. To examine the relationship between short-run fluctuations in money growth and real economic activity, a sample of four industrialized comntries was selected: the United States, the United Kingdom, West Germany and Italy. Moreover, to make the results of the analysis directly comparable, the narrow definition of money for each country is used. ${ }^{10}$

To illustrate the relationship between short-run money growth and real output growth, chats for each country are presented for the period 1973 to the present. ${ }^{11}$ These charts depict the deviations of short-run money growth from its trend, measured by subtracting the 20-quarter moving average growth rate of money from its two-quarter moving average growth rate. In addition, the quarter-to-quarter, compounded ammal rate of growth of real GNP is

\footnotetext{
Whe Ml definition is ased throughout. If shoud be noted that even thomgh the narrow definition is used, it is not the variable ased by all the central bunks in thein policy deliberations. The countries and their respective nometary targets are: United States (M1, M2), United Kingdom (Sterling M3), Gemany Central Bank Money Stock) and ltaly (Total Domestic Credit).

IThe period since 1973 is used for two reasons. Finst. it is chat atcrized as a flexible exchange rate period, a condition giving each country more control over its own domestic noney supply and, hence economic ativity than in a fixed exchange rate period. While the analysis also applies to a fixed exchange rate period, economic activity of open economies durng such at period may merely reflect economic activity in the United States. Consecuently, we chose the post-1973 period because we are concened with examining the impact of changes in short-run money arow th that atre motivated by changes in factors indigenous to the domestie econme. Second, this period covers tle time in which cach contry sentral bank announced a monetary aggregate policy target. Prior to 1973 , announced money sapply grawth targets were not universal.
} 
plotted. Periods in which real output growth was negative for two consecutive quarters or more are denoted by the shaded areas; these designate periods of recession in these countries. ${ }^{12}$

The individual charts reveal that there is a common relationship between sharp reductions in the short-rum growth of money (the two-quarter moving average) relative to its trend (the 20 -quarter moving average) and real economic activity. ${ }^{13}$ Despite the wide differences among these countries in terms of their financial structures, regulations and monetary policy objectives, the relationship between shortrun deviations in their money growth from trend and declines in their real economic activity is quite similar. To see this more clearly, we briefly examine the historical record of each country in our sample.

\section{The Unhat sumes}

The chart for the United States reveals three recessions since 1973. As predicted by the theoretical discussion, each recession was preceded by a shap slowing in short-rum money growth. Prior to the 1974 recession, for example, short-run money growth fell from slightly over 2 percentage points above trend to about 2 percentage points below trend, a change that is mirrored in the reduction in real GNP growth in 1973. While one may argue that the recession of 1974 was supply-oriented - a reaction to the unexpected OPEC oil shock - the chart indicates that the depth and breadth of the downtum was exacerbated by short-run money growth well below trend in late 1974.14

\footnotetext{
${ }^{12}$ The recessions in the United States are those defined by the National Bumea of Economic Research. Since recessions are not fomally defined in the other countries in the sumple, the generally accepted rule of thumb is that a recession is indicated by at least wo consecutive quarters of declining real GNP.

aThe purpose of this article is not to employ statistical methods to investigate rigorously the money/real output relationship in those countries. Instead, we are simply applying the general implications of the reseat that has been conducted for the United States to an analysis of these commtries, ats a first attempt to see if empinical relationships smilar to those in the United States an be found Obviously, the timing of the money grow th real output relationship may be different across countries and, in fact the 20-muarter and two-quarter distinctions may not be completely applicable to all. The seresalts, however, appear to be quite robust and, consefuents, we shift to the uncomvinced reader the obligation of an al temative interpretation of the data.

${ }^{14}$ The oil price shocks of $1973-74$ and $1979-80$ resnlted in dissinilat monetary growth rates in the United States. For a discussion of this, see R. W. Hafer, "The Impact of Energy Prices and Money Growth on Five Industrial Countres." this Retete (March 1981), pp. 19.26.
}

The most recent downtums in economic activity also are associated with declines in short-run money growth. For example, prior to the onset of the II/ 1980-11L/1980 recession, money growth fell from atbout 3 percentage points above trend to over 4 percentage points below trend. Although money growth's sharp rebound during late 1980 helped produce the turnaround in real GNP growth in eary 1981, the equally dramatic downtum in money growth relative to trend during 1981 has precipitated yet another reduction in real economic activity. Indeed, since $1 / 1980$, short-run money growth has fallen short of trend almost 90 percent of the time, and real GNP growth has been negative almost 40 percent of the time. Clearly, the dramatic slowing in short-run money grow th relative to its long-run trend and the increase in its volatility during the past two years have been associated with substantial reductions in real economic activity over this period.

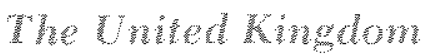

The accompanying chart indicates that the United Kingdom has experienced a number of "recessions" during the brief period studied. Of the six recessions shown, all but one were preceded by sharp reductions in short-run money growth. For instance, prior to the IV/1973-1/1974 downtum, money growth fell from about 5 percentage points above trend to more than 10 percentage points below trend, a reversal of about 15 percentage points in less than one year. Likewise, the $\mathrm{I} / 1977-\mathrm{II} / 1977$ recession came on the heels of a drop in money growth to more than 5 percentage points below its trend.

The period since late 1978 is in teresting because it reveals the effect on the economy of at sustained reduction in short-run money growth below its trend. Although money growth did not dip far below trend prior to the $I V / 1978-\mathrm{I} / 1979$ recession, shortrun money growth fell from over 15 percentage points above trend in IV/1977 to its trend level in only three quarters, a change that is associated with the drop in real GNP growth from IV/1977 to 1/1979. Also, the impact of the nature of the money growth decline during the period from IV/1977 to I/1981 is reflected by relatively stagnant output growth during this period.

Finally, the IV/1974-III/1975 recession represents an anomaly to the theory. The recession was not preceded by a downturn in short-run money growth relative to its trend; instead, money growth increased faster than its trend rate prior to this reces- 


\section{Money and Ouput Growth in Selected Countries}



\section{Money and Output Growth in Selected Countries}
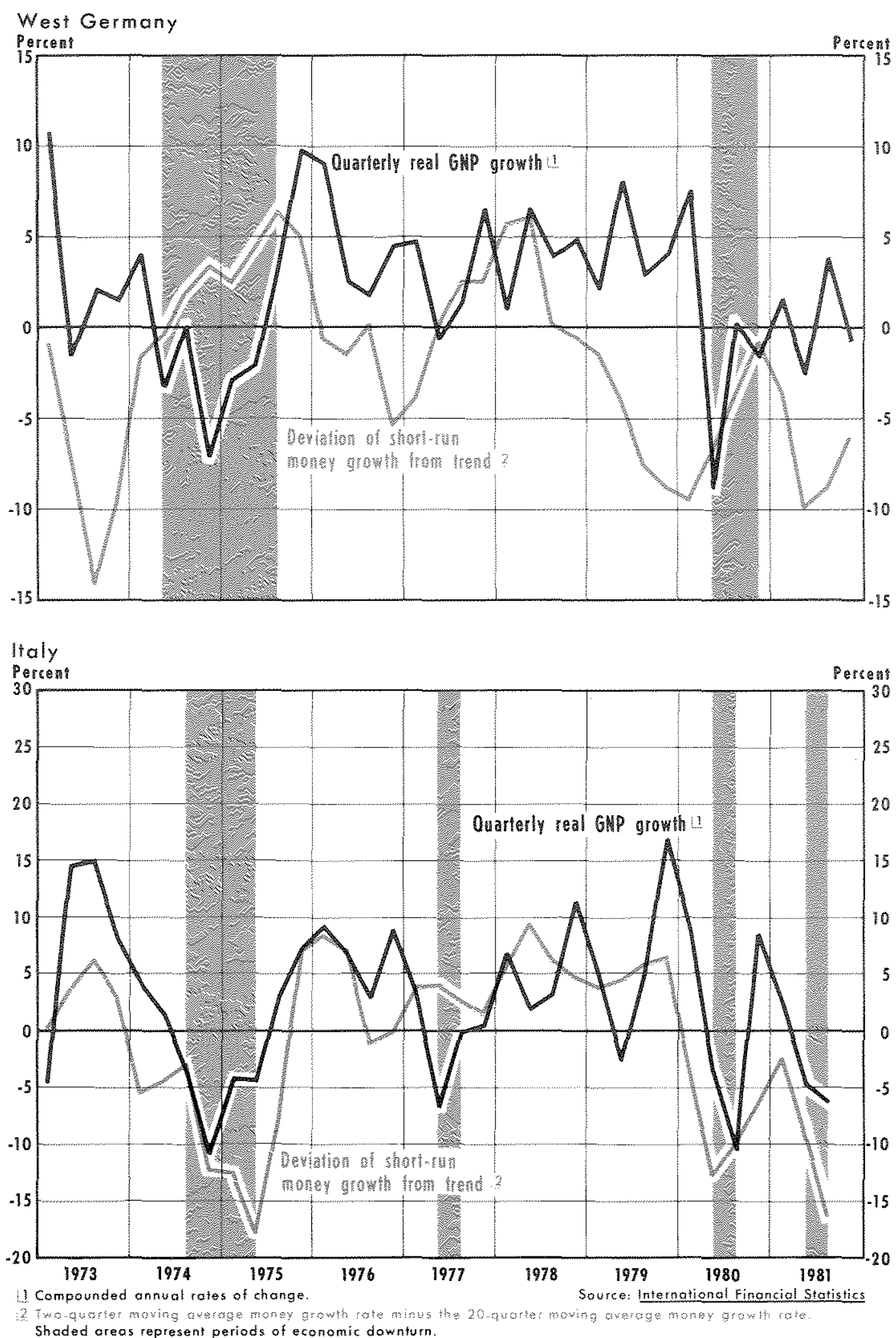
sion. This may have been an attempt to use monetary policy to offset, at least partially, the dislocations created by the OPEC oil shock that lowered the grow th of real GNP. Interestingly, the U.K. response to the 1978-79 OPEC oil shock was to decrease the shortmun growth of the money stock, as shown in the chart. ${ }^{15}$

\section{West Cermant}

The chart for West Germany again supports the theoretical discussion. Each of the two recessions is preceded by periods of money growth below trend. Although the timing is different for each episode, the reaction of the real economy to declines in shortrun money growth is clear and consistent.

West Germany also presents a case in which money growth fell below trend and no technical recession occurred. From III/1975 to IV/1976, money growth fell from about 7 percentage points above trend to about 5 percentage points below trend. Although no recession followed, the level of real GNP growth fell sharply as the theory predicts; the growth rate of real GNP fell from about 10 percent in IV/1975 to zero in II/1977. Thus, while technically no recession followed the decline in money growth, real GNP growth was curtaled shamply, an example of a "growth recession."

\section{Italy}

The relationship between real GNP growth and money growth relative to trend in Italy, once again, is consistent with theoretical expectations. Of the three recessions since 1973 , each was preceded by a period of sharp reductions in short-run money

\footnotetext{
"Hafer, "Impact of Energy Prices and Money Growth."
}

growth relative to its trend rate. This pattem is especially evident for the II/1974-II/1975 and II/1980III/1980 recessions.

\section{CONCUSONS}

The evidence presented here suggests that sizable and sustained reductions in short-run money growth below its trend rate portend declines in the growth of real GNP. Of the 14 recessions in the four countries examined, only one - the IV/1974-111/1975 recession in the United Kingdom - was not preceded by a substantial decline in short-run money growth. Moreover, in only one instance - the III/1975-IV/ 1976 period for West Germany - did short-run money growth fall substantially below trend without a recession following. In that instance, however, West German real GNP growth fell from about 10 percent to zero, a result consistent with the theoretical discussion.

Thus, the evidence indicates that policymakers should be concemed with short-run fuctuations in the growth of the money supply relative to its trend. ${ }^{16}$ If this evidence is at all useful, it demonstrates how robust the relationship between money grow th and real economic activity is over the short run. Coupled with previously reported research indicating a direct, positive link between longerterm money growth and inflation, the empirical evidence favors a steady growth of the money stock in both the short and long run as the most effective means of achieving economic stability.

197his evidence contradicts the recent claim that "the Imoney growthl volatility issue itself is a houx. No one as yet hals been able to demonstrate that the reported volatility in money las any mpact on either the pace of exonomic activity or intation." Aubrey G. Lanston \& Co, Inc, Newsletter (March 22, 1982).

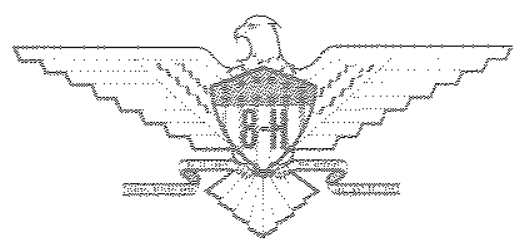

